\title{
Microbiological characterization of table olives commercialized in Portugal in respect to safety aspects
}

\author{
Ana Paula Pereira, José Alberto Pereira, Albino Bento, M. Letícia Estevinho* \\ CIMO/Escola Superior Agrária, Instituto Politécnico de Bragança, Campus Santa Apolónia, Apartado 1 172, 5301-855 Bragança, Portugal
}

\section{A R T I C L E I N F O}

Article history:

Received 15 April 2008

Accepted 29 May 2008

\section{Keywords:}

Table olives

Microbiological characterization

Food safety

\begin{abstract}
A B S T R A C T
Table olives are a traditional component of the Mediterranean diet and are largely consumed in the world. There are different trade treatments that originate different types of olives. The aim of the present work was to proceed to the microbiological characterization of table olives commercialized in the Portuguese market, with respect to their microbiological safety. The microbiological characterization was made in the olive pulp and packing brine of thirty-five table olives samples of different types and trade treatments, namely natural olives $C v$. Galega (NOG), natural turning colour olives (NTCO), green olives (GO), black ripe olives (BO) and natural olives purchased in the traditional market and obtained from traditional producers (NOt). Simultaneously it was verified specific legislation of the table olives in what it concerns to labeling rules, $\mathrm{pH}$ values and the identification of isolated yeasts. In general, table olives consumed showed acceptable security with exception of four NOt samples that presented Staphylococcus aureus. In a considerable number of samples high number of microorganisms indicators of contaminations were observed that reveals the need of optimization the hygienic procedures during production process to improve the quality and safety of table olives. During the work seven yeasts were isolated from olive pulp and brine.
\end{abstract}

(c) 2008 Elsevier Ltd. All rights reserved.

\section{Introduction}

The production of table olives in the world is mainly concentrated in the Mediterranean region. And in European Union, Spain, Italy, Greece, Portugal and France are producer countries. Table olives are a traditional Mediterranean product and, like olive oil and red wine, are one of the most important components of the Mediterranean diet.

The Trade Standard Applying to Table Olives (COI/OT/NC no. 1, 2004) define table olives as the product "prepared from the sound fruits of varieties of the cultivated olive tree (Oleae europaea L.) that are chosen for their production of olives whose volume, shape, flesh-to-stone ratio, fine flesh, taste, firmness and ease of detachment from the stone make them particularly suitable for processing”. Different kinds should be classified according to the fruit ripeness stage, trade preparation, styles and sizing.

There are three main trade preparations of table olives, namely green or Spanish-style olives, black ripe or Californian-style olives and naturally black or turning colour olives (Romero et al., 2004; Fernández et al., 1997). The Spanish processing method includes treatment with sodium hydroxide solution, for the total removal of the bitter compound oleuropein, washing, brining and fermenta-

\footnotetext{
* Corresponding author. Tel.: +351 273 303342; fax: +351 273325405 .

E-mail address: leticia@ipb.pt (M.L. Estevinho).
}

tion, sorting and size grading and packaging (Romero et al., 2004). The Californian method of treatment includes lye treatment, washing, iron-salt treatment and air-oxidation, washing, sizing, canning and sterilisation (Marsilio et al., 2001). The Greek-style method of treatment is milder and includes washing, natural fermentation in brine, air-oxidation for colour improvement, sizing and packing (Boskou et al., 2006).

No official microbiological criteria for table olives are available. However, the Standard 66-1981 (Rev. 1-1987) of the Codex Alimentarius (Anonymous, 1987) prescribed the minimum requirements related to hygiene for table olives. And the final product shall be free from microorganisms and parasites in amounts which may represent a hazard to health and shall not contain any substance originating from microorganisms in amounts which may represent a hazard to health. According to COI (2004) fermented olives held in bulk in a covering liquid may contain lactic bacteria and/or yeasts used for fermentation. The number of such microorganisms in a selective culture medium may, for each one, be up to $10^{9}$ colony forming units $/ \mathrm{mL}$ of brine or per gramme of flesh depending on the level of fermentation. On the other hand, olives preserved by heat sterilisation (such as olives darkened by oxidation) shall have received a processing treatment sufficient both in time and temperature to destroy spores of Clostridium botulinum (COI, 2004).

The most important safety issue in fermented olives appears to be the risk of $C$. botulinum growth and toxin formation. In spite of black olives were incriminated in a small outbreak of botulism of 
the B type, the occurrence of $C$. botulinum appears, however, to be rare (Nout and Rombouts, 2000).

The aim of this work was to proceed to the microbiological characterization of table olives commercialized in the Portuguese market. The microbiological characterization occurred in olive pulp and packing brine of thirty-five table olives samples of different types and trade treatments, namely natural olives $C v$. Galega (NOG), natural turning colour olives (NTCO), green or Spanish-style olives (GO), black ripe or Californian-style olives (BO) and natural olives purchased in the traditional market and obtained from traditional producers (NOt). Simultaneously it was verified specific legislation of the table olives in what it concerns to labeling rules. The isolated yeasts were also identified.

\section{Materials and methods}

\subsection{Samples}

Thirty-five table olives samples were studied (Table 1). Seven samples were classified as natural olives in brine (black and turning colour olives) CV. Galega (NOG) and were purchased in a supermarket. Seven samples were from natural turning colour olives in brine (NTCO) and were also obtained in a supermarket. Seven samples were classified as green olives (GO), produced by the Spanish method and were purchased in a supermarket. Seven samples were classified as ripe black olives (BO), produced by the Californian method, of which four samples were purchased in a supermarket; two were purchased in the traditional market and one was obtained directly from an industrial producer. The last seven samples, obtained from traditional producers and purchased in traditional market, were produced by the traditional method and classified as turning colour olives in brine (NOt).

\subsubsection{Labeling}

The labeling of the table olives purchased in the supermarket were analysed in agreement with the requirements of the current Portuguese legislation, Dec.-Lei no. $170 / 92$ of 8 th August, and the specific mentions referred in the Portuguese Standard NP - 3034 (1987)

\subsection{2. $\mathrm{pH}$}

The $\mathrm{pH}$ was determined, both in the pulp and packing brine of table olives, directly with a Basic $20 \mathrm{pH}$ Meter.

\subsection{Microbiological determinations}

The microbiological analysis was made on the olive pulp and on the packing brine of the container. In order to evaluate the microbiological quality of the table olives it were researched pathogenic microorganisms - Salmonella, and Staphylococcus aureus, - microorganisms indicators of microbial contamination - total coliforms, Escherichia coli, faecal Streptococcus, sulphite reducing Clostridium spores and moulds - and microorganisms involved in the fermentation of the product mesophilic microorganisms and yeasts.

\subsubsection{Samples preparation}

The samples preparation was accomplished according to the Portuguese Standard ISO 6887 - 1 (1999), NP - 1829 (1982), and NP - 3005 (1985). For the olive pulp analyses, two grams of each sample was weighted aseptically and homogenized in a stomacher Seward 400 for two minutes with $20 \mathrm{~mL}$ of sterile Ringer solution $\left(10^{-1}\right.$ dilution). Further $1 \mathrm{~mL}$ of $10^{-1}$ dilution was added to $9 \mathrm{~mL}$ of Ringer solution, and then homogenized $\left(10^{-2}\right.$ dilution). A series of decimal dilutions until $10^{-5}$ dilution, were made with the same solvents. In order to analyse the olives packing brine, $20 \mathrm{~mL}$ of each sample was taken aseptically. Then $1 \mathrm{~mL}$ of the sample was homogenized with $9 \mathrm{~mL}$ of sterile water $\left(10^{-1}\right.$ dilution). Several decimal dilutions were made with the same solvents until $10^{-4}$ dilution was achieved. Water was treated in a Milli-Q water purification system (TGI Pure Water Systems).

\subsubsection{Enumeration of the total mesophilic microorganisms}

Enumeration was made on Plate Count Agar (Himedia), incubated at $37{ }^{\circ} \mathrm{C}$ for $48 \mathrm{~h}$. Results were expressed as colony forming units of mesophilic microorganisms per gram of pulp olive (CFU/g) or per $\mathrm{mL}$ of packing brine $(\mathrm{CFU} / \mathrm{mL})$.

\subsubsection{Yeast and moulds}

Enumeration was made on Potato Dextrose Agar Medium (Himedia) pH 3.5, acidified with tartaric acid, incubated at $25^{\circ} \mathrm{C}$ for 5 days. Results were expressed as colony forming units of yeast and moulds per gram of pulp olive (CFU/g) or per $\mathrm{mL}$ of packing brine $(\mathrm{CFU} / \mathrm{mL})$.

\subsubsection{Salmonella}

Detection according to ISO 6579 (2002). Results were expressed as presence or absence of Salmonella.

\subsubsection{Staphylococcus aureus}

Enumeration was made on CHAPMAN Agar (Culimed Panreac Quimica), incubated at $35^{\circ} \mathrm{C}$ for $48 \mathrm{~h}$. Results were expressed as colony forming units of $S$. aureus per gram of pulp olive (CFU/g) or per $\mathrm{mL}$ of packing brine $(\mathrm{CFU} / \mathrm{mL})$.

\subsubsection{Total coliforms}

Enumeration was made according to the conventional method described in Bacteriological Analytical Manual Online of U.S. Food and Drug Administration (http:// www.cfsan.fda.gov/ ebam/bam-toc.html), using the most probable number (MPN) technique. The MPN in each sample was determined using the FDA online MPN table (http://www.cfsan.fda.gov/ ebam/bam-a2.html). Results were expressed as most probable numbers of coliforms per gram of pulp olive (MPN/g) or per $\mathrm{mL}$ of packing brine $(\mathrm{MPN} / \mathrm{mL})$.

\subsubsection{Escherichia coli}

The positive results for total coliforms were researched for $E$. coli. Enumeration was made on T.B.X. Agar (Oxoid), incubated at $44{ }^{\circ} \mathrm{C}$ for $24 \mathrm{~h}$. Results were expressed as colony forming units of $E$. coli per gram of pulp olive (CFU/g) or per $\mathrm{mL}$ of packing brine $(\mathrm{CFU} / \mathrm{mL})$.

\subsubsection{Fecal streptococci}

Detection on BAGG Broth (HiMedia), incubated at $44{ }^{\circ} \mathrm{C}$ for $48 \mathrm{~h}$. Results were expressed as presence or absence of faecal streptococci.

\subsubsection{Sulphite reducing Clostridium spores}

Detection according to Portuguese Standard NP 2262 (1986). Results were expressed as presence or absence of sulphite reducing Clostridium spores.

\subsection{Isolation and identification of yeasts}

The yeasts isolated from samples of pulp and packing brine were identified with the API 20C Aux system. The system consists of a disposable plastic strips containing 20 cupules. The first copula is a negative control, while the second contains glucose and serves as a positive control. The remaining 18 cupules each contain a specific substrate that may be assimilated by the test organism. After the distribution of about $5 \mathrm{~mL}$ of distilled water in the incubation box it was placed the strip. Isolates, which were cultured in YPD agar plates and incubated $48 \mathrm{~h}$ at $25^{\circ} \mathrm{C}$, were picked up with a sterile loop from the YPD plates and were added to a $\mathrm{NaCl} 0.85 \%$ medium to constitute a suspension. The turbidity of the suspension was equal to 2 MacFarland standard. Hundred microliters of this suspension were transferred to an ampule of API C Medium and homogenized. The cupules were filled with the suspension obtained in the ampule of API C Medium according with the manufacturer's directions. The strips were incubated at $25{ }^{\circ} \mathrm{C}$ and read at 24,48 , and $72 \mathrm{~h}$. A profile number was generated for each isolate depending upon the reactions it produced. Identifications were made by referring to the API 20C AUX - Analytical Profile Index (Anonymous, 1997).

\section{Results and discussion}

\subsection{Labeling and information to consumers}

The analysis of the samples label is summarized in Table 1. Table olives shall be labeled according to Portuguese legislation (D.L. no. 170/92 of August 8th) and NP-3034 (1987) for generic and specific inscriptions, respectively. The generic inscriptions, obligatory mentioned in the label of the container, are the name of the product, the list of ingredients, the net weight, the date of minimum durability, the lot identification and the name, firm or social denomination and the address of the manufacturer, packer, distributor or vendor of the product, established in the European Union. All analyzed samples presented the name of the product, "olives" or "table olives", the list of ingredients listed in descending order 
Table 1

Registration in the label of table olive samples

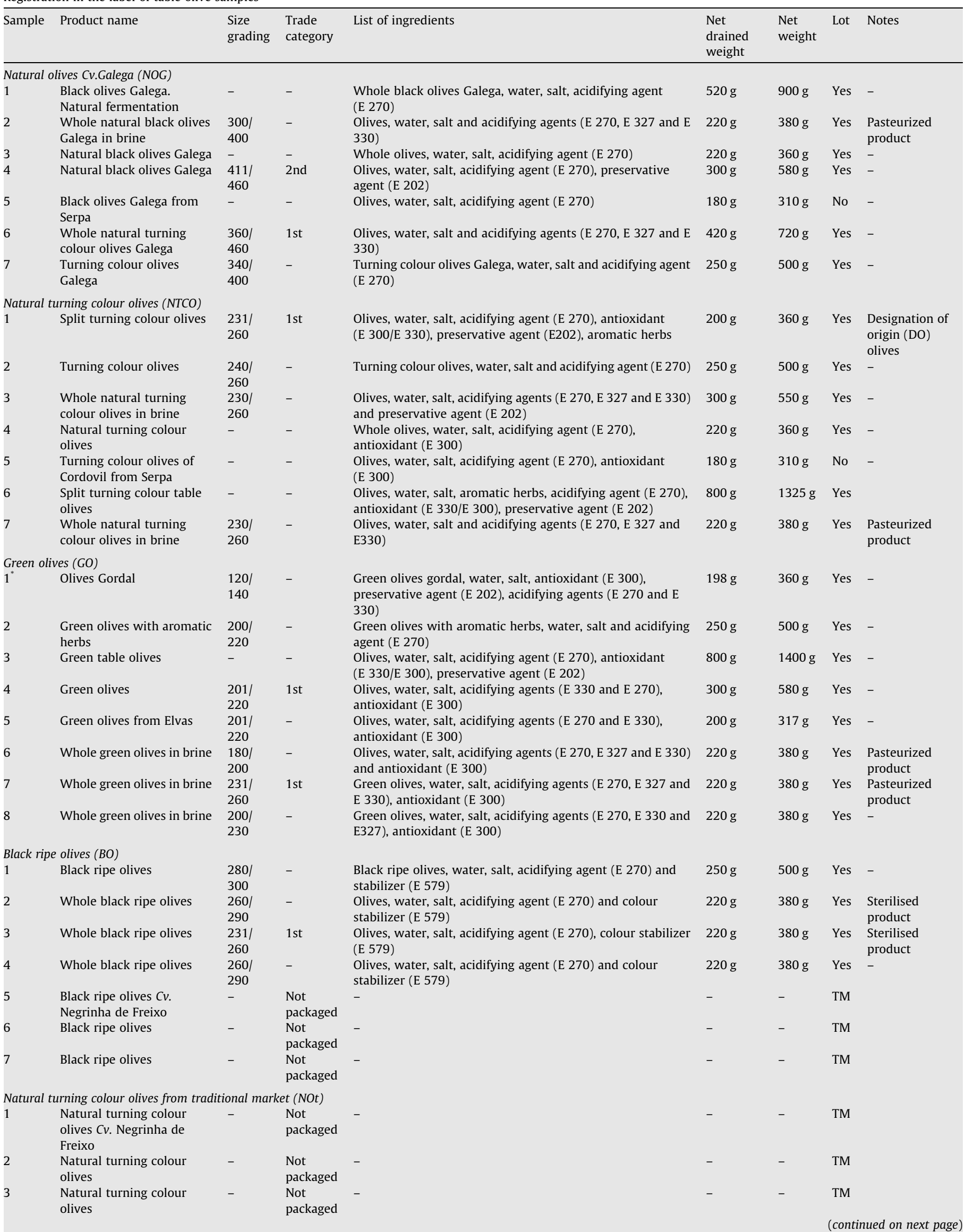


Table 1 (continued)

\begin{tabular}{|c|c|c|c|c|c|c|c|c|}
\hline Sample & Product name & Size grading & Trade category & List of ingredients & Net drained weight & Net weight & Lot & Notes \\
\hline 4 & Natural turning colour olives & - & Not packaged & - & - & - & $\mathrm{TM}$ & \\
\hline 5 & Natural turning colour olives & - & Not packaged & - & - & - & TM & \\
\hline 6 & Natural turning colour olives & - & Not packaged & - & - & - & $\mathrm{TM}$ & \\
\hline 7 & Split natural turning colour olives & - & Not packaged & - & - & - & $\mathrm{TM}$ & \\
\hline
\end{tabular}

of ingoing weight and the date of minimum durability declared by month and year, and in some cases by day. The net weight and drained weight were declared in all samples but in six of them (samples 3 and 7 of NOG, 2 and 4 of NTCO, 2 of GO and 1 of BO), the units were not showed in the metric system. Lot identification was not referred in two samples (samples 5 of NOG and 5 of NTCO). The remaining inscriptions were fulfilled in all samples (Table 1).

According to the NP-3034 (1987) the specific inscriptions that shall be in the label of the container are the name of product "Olives" or "Table olives" followed by type of olives ("Green", "Turning colour" or "Black"), style ("Whole olives", "Split olives", "Stoned olives", "Stuffed olives" and "Sliced olives"), size grading, trade category ("Extra", "First" or "Second") and net drained weight. One sample (sample 1 of GO) did not refer the name of the product. Twelve samples had a reference to the style "whole" or "split" olives. The size grading was declared in nineteen samples and the trade category was referred only in six samples (samples 4 and 6 of NOG, 1 of NTCO, 4 and 7 of GO and 3 of BO) (Table 1).

Only one sample (sample 1 of GO) presented additional nutrition labeling per $100 \mathrm{~g}$ of olives and per dosis ( 9 olives $\approx 19 \mathrm{~g}$ ). According the producer $100 \mathrm{~g}$ of olives have energetic value of $578.5 \mathrm{~kJ} / 140 \mathrm{kcal}, 0.0 \mathrm{~g}$ of protein; $5.3 \mathrm{~g}$ of carbohydrates and $13.2 \mathrm{~g}$ of lipids. Per dosis was mentioned: energetic value of $109.5 \mathrm{~kJ} / 26.5 \mathrm{kcal}, 0.0 \mathrm{~g}$ of protein; $1 \mathrm{~g}$ of carbohydrates and $2.5 \mathrm{~g}$ of lipids. Sodium level was also mentioned, less than $1000 \mathrm{mg} /$ $100 \mathrm{~g}$ of olives and $190 \mathrm{mg} /$ dosis. However, no information was given about saturated fatty acids and crude fiber content (D.L. no. $167 / 2004$ of July 7 th).

Concerning to additives several are mentioned in the labeling: acidifying agents (lactic acid - E 270 and calcium lactate - E327), antioxidants (ascorbic acid - E 300 and citric acid - E 330), preservative agent (potassium sorbate - E 202), colour stabilizer (E 579). All these chemical products could have toxicological implications; however additives have also an important role in food preservation and in the increasing and maintenance of their biological properties. In the samples of this work, all NOG, NTCO, GO and BO mentioned the presence of lactic acid (E 270) as acidifying agent. With the same functions calcium lactate (E 327) were added at two NOG, two NTCO and three GO samples. Two samples of NOG, three of NTCO and all of GO refers the presence of citric acid as antioxidant, and four NTCO and all the GO refers also the use of ascorbic acid (E 300). Only BO refers the use of ferrous gluconate (E 579) which is related with the production process and the necessity to stabilize the colour (black).

\subsection{Hygienic status of samples and influence of table olive type}

The $\mathrm{pH}$ values measured for the table olive pulp and packing brine are shown in Table 2 . The maximum pH limits of brines must comply with NP-3034 (1987), and are different according to type and treatment. The pH levels stipulated should be between 4 and 4.5 for GO whereas for pasteurized $\mathrm{BO}$ the $\mathrm{pH}$ could be up to 5.5 . The maximum $\mathrm{pH}$ for pasteurized green and turning colour olives and for sterilised olives is 4.3 and 8.0, respectively.

Generally, it was verified that the $\mathrm{pH}$ value was similar both in the olive pulp and in the packing brine, with the exception of sample one of NOG, in which the pH value of the pulp was lower (4.3) than the one of the brine (5.9). The raising of $\mathrm{pH}$ of this sample may be related with microbiological changes that might be happening in the packing brine. Since the standard does not refer the maximum $\mathrm{pH}$ limit for NTCO, it can be applied the maximum $\mathrm{pH}$ limit of 4.0 for GO, treated or untreated, in hermetically-sealed containers (Fernández et al., 1997). Thus, almost all samples presented a $\mathrm{pH}$ lower to the established, with the exception of the packed samples 3 and 4 of GO and NOt.

Concerning the microbiological analysis of table olives samples, shown in Tables 3 and 4, great variability was observed between pulp and packing brine and between trade treatments.

Total mesophilic microorganisms, in which are included the lactic acid bacteria and yeasts were the dominant microflora, once they play an important role in the fermentation of table olives. These microorganisms were detected essentially in NOt and were

Table 2

$\mathrm{pH}$ value of the pulp and packing brine of the table olives samples

\begin{tabular}{|c|c|c|}
\hline \multirow[t]{2}{*}{ Samples } & \multicolumn{2}{|l|}{$\mathrm{pH}$} \\
\hline & Pulp & Brine \\
\hline \multicolumn{3}{|c|}{ Natural olives Cv. Galega } \\
\hline 1 & 4.3 & 5.9 \\
\hline 2 & 3.8 & 3.7 \\
\hline 3 & 3.4 & 3.5 \\
\hline 4 & 3.9 & 3.9 \\
\hline 5 & 4.0 & 4.1 \\
\hline 6 & 3.7 & 3.6 \\
\hline 7 & 3.4 & 3.4 \\
\hline \multicolumn{3}{|c|}{ Natural turning colour olives } \\
\hline 1 & 3.7 & 3.6 \\
\hline 2 & 4.0 & 4.0 \\
\hline 3 & 3.7 & 3.7 \\
\hline 4 & 3.6 & 3.5 \\
\hline 5 & 3.4 & 3.6 \\
\hline 6 & 3.7 & 3.7 \\
\hline 7 & 3.4 & 3.4 \\
\hline \multicolumn{3}{|c|}{ Green olives } \\
\hline 1 & 3.6 & 3.7 \\
\hline 2 & 3.7 & 3.8 \\
\hline 3 & 4.5 & 4.5 \\
\hline 4 & 4.2 & 4.3 \\
\hline 5 & 3.5 & 3.6 \\
\hline 6 & 3.4 & 3.5 \\
\hline 7 & 4.1 & 4.1 \\
\hline 8 & 3.7 & 3.8 \\
\hline \multicolumn{3}{|c|}{ Black ripe olives } \\
\hline 1 & 4.5 & 4.6 \\
\hline 2 & 6.2 & 6.1 \\
\hline 3 & 7.0 & 6.7 \\
\hline 4 & 7.1 & 6.7 \\
\hline 5 & 5.8 & 6.3 \\
\hline 6 & 5.4 & 5.5 \\
\hline 7 & 5.4 & 5.5 \\
\hline \multicolumn{3}{|c|}{ Natural turning colour olives from traditional market/producer } \\
\hline 1 & 5.5 & 5.5 \\
\hline 2 & 4.4 & 4.3 \\
\hline 3 & 4.5 & 4.4 \\
\hline 4 & 4.2 & 4.1 \\
\hline 5 & 4.4 & 4.4 \\
\hline 6 & 5.3 & 5.3 \\
\hline 7 & 4.4 & 4.4 \\
\hline
\end{tabular}


Table 3

Microbiological characterization of the pulp of table olives samples

\begin{tabular}{|c|c|c|c|c|c|c|c|c|c|}
\hline Samples & $\begin{array}{l}\text { Total mesophilic microorganisms } \\
(\mathrm{CFU} / \mathrm{g})\end{array}$ & $\begin{array}{l}\text { Yeasts } \\
(\mathrm{CFU} / \mathrm{g})\end{array}$ & $\begin{array}{l}\text { Moulds } \\
(\mathrm{CFU} / \mathrm{g})\end{array}$ & $\begin{array}{l}\text { Total coliforms } \\
(\mathrm{MPN} / \mathrm{g})\end{array}$ & $\begin{array}{l}\text { E. coli } \\
(\mathrm{CFU} / \mathrm{g})\end{array}$ & Salmonella & $\begin{array}{l}\text { S. aureus } \\
\text { (CFU/g) }\end{array}$ & $\begin{array}{l}\text { Fecal } \\
\text { Streptococci }\end{array}$ & $\begin{array}{l}\text { SRC } \\
\text { spores }\end{array}$ \\
\hline \multicolumn{10}{|c|}{ Natural olives Cv. Galega } \\
\hline 1 & 0.0 & 0.0 & 0.0 & 0.0 & 0.0 & - & 0.0 & - & + \\
\hline 2 & 0.0 & 0.0 & 0.0 & 0.0 & 0.0 & - & 0.0 & - & + \\
\hline 3 & 0.0 & 0.0 & 0.0 & 0.0 & 0.0 & - & 0.0 & - & + \\
\hline 4 & 0.0 & 0.0 & 0.0 & 0.0 & 0.0 & - & 0.0 & - & + \\
\hline 5 & 0.0 & 0.0 & 0.0 & 0.0 & 0.0 & - & 0.0 & - & + \\
\hline 6 & 0.0 & 0.0 & 0.0 & 0.0 & 0.0 & - & 0.0 & - & + \\
\hline 7 & 0.0 & 0.0 & 0.0 & 0.0 & 0.0 & - & 0.0 & - & + \\
\hline \multicolumn{10}{|c|}{ Natural turning colour olives } \\
\hline 1 & 0.0 & 0.0 & 0.0 & 0.0 & 0.0 & - & 0.0 & - & + \\
\hline 2 & 0.0 & 0.0 & 0.0 & 0.0 & 0.0 & - & 0.0 & - & + \\
\hline 3 & 0.0 & 0.0 & 0.0 & 0.0 & 0.0 & - & 0.0 & - & + \\
\hline 4 & 0.0 & 0.0 & 0.0 & 0.0 & 0.0 & - & 0.0 & - & + \\
\hline 5 & 0.0 & $2.0 \times 10^{3}$ & 0.0 & 0.0 & 0.0 & - & 0.0 & - & + \\
\hline 6 & 0.0 & & & 0.0 & 0.0 & - & 0.0 & - & - \\
\hline 7 & 0.0 & 0.0 & 0.0 & 0.0 & 0.0 & - & 0.0 & - & - \\
\hline \multicolumn{10}{|c|}{ Green olives } \\
\hline 1 & 0.0 & 0.0 & 0.0 & 0.0 & 0.0 & - & 0.0 & - & + \\
\hline 2 & 0.0 & 0.0 & 0.0 & 0.0 & 0.0 & - & 0.0 & - & + \\
\hline 3 & 0.0 & 0.0 & 0.0 & 0.0 & 0.0 & - & 0.0 & - & + \\
\hline 4 & 0.0 & 0.0 & 0.0 & 0.0 & 0.0 & - & 0.0 & - & + \\
\hline 5 & 0.0 & 0.0 & 0.0 & 0.0 & 0.0 & - & 0.0 & - & + \\
\hline 6 & 0.0 & 0.0 & 0.0 & 0.0 & 0.0 & - & 0.0 & - & + \\
\hline 7 & 0.0 & 0.0 & 0.0 & 0.0 & 0.0 & - & 0.0 & - & + \\
\hline 8 & 0.0 & 0.0 & 0.0 & 0.0 & 0.0 & - & 0.0 & - & + \\
\hline \multicolumn{10}{|c|}{ Black ripe olives } \\
\hline 1 & 0.0 & 0.0 & 0.0 & 0.0 & 0.0 & - & 0.0 & - & + \\
\hline 2 & 0.0 & 0.0 & 0.0 & 0.0 & 0.0 & - & 0.0 & - & + \\
\hline 3 & 0.0 & 0.0 & 0.0 & 0.0 & 0.0 & - & 0.0 & - & + \\
\hline 4 & 0.0 & 0.0 & 0.0 & 0.0 & 0.0 & - & 0.0 & - & + \\
\hline 5 & $1.4 \times 10^{5}$ & $1.1 \times 10^{6}$ & 0.0 & 0.0 & 0.0 & - & 0.0 & - & + \\
\hline 6 & 0.0 & $4.9 \times 10^{4}$ & 0.0 & 0.0 & 0.0 & - & 0.0 & - & + \\
\hline 7 & 0.0 & $8.3 \times 10^{5}$ & 0.0 & 0.0 & 0.0 & - & 0.0 & - & + \\
\hline \multicolumn{10}{|c|}{ Natural turning colour olives from traditional market/producer } \\
\hline 1 & $1.0 \times 10^{3}$ & $7.0 \times 10^{3}$ & 0.0 & 0.0 & 0.0 & - & 0.0 & - & + \\
\hline 2 & 0.0 & $2.0 \times 10^{5}$ & 0.0 & 0.0 & 0.0 & - & 0.0 & - & + \\
\hline 3 & Uncountable & $1.1 \times 10^{5}$ & 0.0 & 0.0 & 0.0 & - & 0.0 & - & + \\
\hline 4 & Uncountable & $7.6 \times 10^{4}$ & 0.0 & 0.0 & 0.0 & - & 0.0 & - & + \\
\hline 5 & $1.5 \times 10^{5}$ & $8.2 \times 10^{4}$ & 0.0 & 0.0 & 0.0 & - & 0.0 & - & + \\
\hline 6 & $1.0 \times 10^{3}$ & $1.2 \times 10^{5}$ & $1.3 \times 10^{4}$ & 0.0 & 0.0 & - & 0.0 & - & + \\
\hline 7 & $3.2 \times 10^{4}$ & $1.9 \times 10^{6}$ & $2.0 \times 10^{3}$ & 0.0 & 0.0 & - & 0.0 & - & + \\
\hline
\end{tabular}

present in higher levels in packing brine than in the pulp, probably due to the values of water activity $\left(a_{\mathrm{w}}\right)$ and to the phenolic compounds present in the olive's pulp (Pereira et al., 2006; Sousa et al., 2008). Natural olives are fermented predominantly by yeasts (Fernández et al., 1997; Nout and Rombouts, 2000), which could explain their detection in higher levels than total mesophilic microorganisms. In fact, unlike lactic acid bacteria, yeasts are more tolerant to high $\mathrm{NaCl}$ concentrations and to phenolic compounds, such as oleuropein (Asehraou et al., 2000; Borcakli et al., 1993). The exception was NOG that presented more samples with total mesophilic than yeasts. Similar results were mentioned by Oliveira et al. (2004) for Galega olives at the end of fermentation with the number of yeasts of was about $10^{5} \mathrm{CFU} / \mathrm{mL}$. Lactic acid bacteria play a dominant role in the fermentation of green olives in brine (Asehraou and Faid, 1993; Nout and Rombouts, 2000). The pH values determined in the samples 3 and 4 of GO were higher than the stipulated and were near the $\mathrm{pH}$ optimum value for the growing of yeasts, detected in these two samples. The fermentative yeasts contribute to the organoleptic characteristics of table olives but oxidative yeasts that occur in superficial films should be kept low by anaerobiosis, as they oxidize lactic acid, raise the $\mathrm{pH}$, and thereby may favour malodorous spoilage by Clostridium spp. (Nout and Rombouts, 2000).
Moulds counts are used to detect fungal contamination (Anonymous, 2004), and were present in two pulp and six brine samples mainly from NOt. Probably this situation was related with air surface of brine in tanks or barrels. Excessive mould growth origin a mouldy taste in olives and can cause spoilage by consuming the acids produced during fermentation (Anonymous, 2004). Eltem (1996) isolated Aspergillus flavus strains from natural black olives in brine and Roussos et al. (2006) confirmed the accumulation of micotoxins in the brines of fermentation that could compromises the safety of the product.

Concerning the microorganisms indicators of contamination, it can be inferred that most of the NOt were produced under deficient hygiene conditions. Total coliforms were only detected in packing brine of table olive samples that came from traditional market. These microorganisms are indicators of recent faecal contamination, so their presence in the samples reveals lack of good practices of hygiene during or after the manufacturing, but the levels determined do not represent a hazard to health. However, coliform bacteria are responsible for gassy spoilage. E. coli is used to monitor the potential for food poisoning and should be tested in pasteurized packed olives for health and safety purposes (Anonymous, 2004).

Faecal streptococci or enterococci were absent in the pulp but were detected in six samples of brine, namely in one sample of 
Table 4

Microbiological characterization of the packing brine of table olives samples

\begin{tabular}{|c|c|c|c|c|c|c|c|c|c|}
\hline Samples & $\begin{array}{l}\text { Total mesophilic } \\
\text { microorganisms (CFU/mL) }\end{array}$ & $\begin{array}{l}\text { Yeasts } \\
(\mathrm{CFU} / \mathrm{mL})\end{array}$ & $\begin{array}{l}\text { Moulds } \\
(\mathrm{CFU} / \mathrm{mL})\end{array}$ & $\begin{array}{l}\text { Total coliforms } \\
(\mathrm{MPN} / \mathrm{mL})\end{array}$ & $\begin{array}{l}\text { E. coli } \\
\text { (CFU/ } \\
\mathrm{mL})\end{array}$ & $\begin{array}{l}\text { Salmonella } \\
(\mathrm{CFU} / \mathrm{mL})\end{array}$ & $\begin{array}{l}\text { S. aureus } \\
(\mathrm{CFU} / \mathrm{mL})\end{array}$ & $\begin{array}{l}\text { Fecal } \\
\text { Streptococci }\end{array}$ & $\begin{array}{l}\text { SRC } \\
\text { spores }\end{array}$ \\
\hline \multicolumn{10}{|c|}{ Natural olives Cv. Galega } \\
\hline 1 & $6.0 \times 10^{2}$ & 0.0 & 0.0 & 0.0 & 0.0 & - & 0.0 & - & + \\
\hline 2 & 0.0 & 0.0 & 0.0 & 0.0 & 0.0 & - & 0.0 & - & + \\
\hline 3 & 0.0 & 0.0 & 0.0 & 0.0 & 0.0 & - & 0.0 & - & + \\
\hline 4 & 0.0 & $1.4 \times 10^{5}$ & 0.0 & 0.0 & 0.0 & - & 0.0 & - & + \\
\hline 5 & 0.0 & 0.0 & 0.0 & 0.0 & 0.0 & - & 0.0 & - & + \\
\hline 6 & $8.0 \times 10^{3}$ & 0.0 & 0.0 & 0.0 & 0.0 & - & 0.0 & - & + \\
\hline 7 & 0.0 & 0.0 & 0.0 & 0.0 & 0.0 & - & 0.0 & - & + \\
\hline \multicolumn{10}{|c|}{ Natural turning colour olives } \\
\hline 1 & 0.0 & 0.0 & 0.0 & 0.0 & 0.0 & - & 0.0 & - & + \\
\hline 2 & 0.0 & $1.3 \times 10^{5}$ & 0.0 & 0.0 & 0.0 & - & 0.0 & - & + \\
\hline 3 & 0.0 & $3.0 \times 10^{3}$ & $1.0 \times 10^{2}$ & 0.0 & 0.0 & - & 0.0 & - & + \\
\hline 4 & 0.0 & 0.0 & 0.0 & 0.0 & 0.0 & - & 0.0 & - & + \\
\hline 5 & 0.0 & $5.5 \times 10^{2}$ & 0.0 & 0.0 & 0.0 & - & 0.0 & - & + \\
\hline 6 & 0.0 & 0.0 & 0.0 & 0.0 & 0.0 & - & 0.0 & - & + \\
\hline 7 & $1.0 \times 10^{2}$ & 0.0 & 0.0 & 0.0 & 0.0 & - & 0.0 & - & + \\
\hline \multicolumn{10}{|c|}{ Green olives } \\
\hline 1 & 0.0 & 0.0 & 0.0 & 0.0 & 0.0 & - & 0.0 & - & + \\
\hline 2 & $1.0 \times 10^{2}$ & 0.0 & 0.0 & 0.0 & 0.0 & - & 0.0 & - & + \\
\hline 3 & $6.5 \times 10^{2}$ & $1.1 \times 10^{4}$ & 0.0 & 0.0 & 0.0 & - & 0.0 & + & + \\
\hline 4 & 0.0 & $1.0 \times 10^{5}$ & 0.0 & 0.0 & 0.0 & - & 0.0 & - & + \\
\hline 5 & 0.0 & 0.0 & 0.0 & 0.0 & 0.0 & - & 0.0 & - & + \\
\hline 6 & 0.0 & 0.0 & 0.0 & 0.0 & 0.0 & - & 0.0 & - & + \\
\hline 7 & 0.0 & 0.0 & 0.0 & 0.0 & 0.0 & - & 0.0 & - & + \\
\hline 8 & 0.0 & 0.0 & 0.0 & 0.0 & 0.0 & - & 0.0 & - & + \\
\hline \multicolumn{10}{|c|}{ Black ripe olives } \\
\hline 1 & $1.0 \times 10^{2}$ & $7.8 \times 10^{4}$ & 0.0 & 0.0 & 0.0 & - & 0.0 & - & - \\
\hline 2 & 0.0 & 0.0 & 0.0 & 0.0 & 0.0 & - & 0.0 & - & + \\
\hline 3 & 0.0 & 0.0 & 0.0 & 0.0 & 0.0 & - & 0.0 & - & + \\
\hline 4 & 0.0 & 0.0 & 0.0 & 0.0 & 0.0 & - & 0.0 & - & + \\
\hline 5 & 0.0 & Uncountable & 0.0 & 3.6 & 0.0 & - & 0.0 & - & + \\
\hline 6 & $1.6 \times 10^{5}$ & Uncountable & $3.8 \times 10^{3}$ & 93.0 & 0.0 & - & 10.0 & + & + \\
\hline 7 & $1.5 \times 10^{6}$ & $2.5 \times 10^{6}$ & 0.0 & 93.0 & $2.3 \times 10^{4}$ & - & 40.0 & + & + \\
\hline \multicolumn{10}{|c|}{ Natural turning colour olives from traditional market/producer } \\
\hline 1 & $3.7 \times 10^{3}$ & Uncountable & 0.0 & 0.0 & 0.0 & - & 0.0 & - & + \\
\hline 2 & $1.4 \times 10^{4}$ & Uncountable & 0.0 & 0.0 & 0.0 & - & 0.0 & - & + \\
\hline 3 & Uncountable & $3.2 \times 10^{6}$ & 0.0 & 0.0 & 0.0 & - & 0.0 & - & + \\
\hline 4 & Uncountable & Uncountable & $8.1 \times 10^{3}$ & 11.0 & 0.0 & - & 10.0 & + & + \\
\hline 5 & $4.6 \times 10^{4}$ & $6.7 \times 10^{4}$ & $7.3 \times 10^{3}$ & 9.2 & 0.0 & - & 0.0 & - & + \\
\hline 6 & $7.4 \times 10^{5}$ & $3.8 \times 10^{5}$ & $6.3 \times 10^{4}$ & 9.2 & 0.0 & - & 0.0 & + & + \\
\hline 7 & $3.2 \times 10^{5}$ & $5.3 \times 10^{5}$ & $8.6 \times 10^{3}$ & 23.0 & 0.0 & - & 10.0 & + & + \\
\hline
\end{tabular}

GO packed olives and five samples of NOt. The presence of enterococci in fermented vegetables it is often not clear, whether hey originate from the plant material or as environmental contaminants (Franz and Holzapfel, 2004). However, enterococci have already been isolated from Spanish-style green olive fermentations by Floriano et al. (1998), in which E. faecalis is a frequent contaminant.

The sulphite reducing Clostridium (SRC) spores are indicators of remote faecal contamination. They were detected in almost all samples with the exception of two, being even present in pasteurized and sterilised samples. Their presence in pasteurized olives is due to the occurrence of anaerobic fermentations of the product or to the resistance of spores to pasteurization. However, the spores should be destroyed by sterilisation as its presence in a sterilised product indicates either inadequate heat treatment or post-sterilisation contamination. Clostridial bacteria are relatively common in the environment. This kind of bacteria are able to produce spoors that can survive under harsh conditions, such as high temperature and humidity, and have latent potential for spoilage namely malodorous deterioration (putrid, butyric and zapatera spoilage) (Anonymous, 2004).

The levels of the pathogens Salmonella, and S. aureus were accessed since they are a potential food hazard. None of the analysed samples presented Salmonella, but S. aureus was detected in small numbers in the packing brine of four NOt samples. These samples should be considered as unacceptable/potentially hazardous and so improper for consumption, because they can cause food-borne illness. The occurrences of $S$. aureus in dry-salted olives were reported by Asehraou et al. (1992) in samples from Moroccan.

\subsection{Isolation and identification of yeasts}

Seven yeasts species were identified in the analysed samples (Table 5). Five of the identified species belong to Candida genus. Marked differences were observed between pulp and packing brine of table olives. In olive pulp, yeasts were identified in 11 samples, one ( $C$. boidini) in NTCO (sample 5); three in BO (samples 5-7) with the same species and all NOt showed the presence of yeasts. On the other side, in olive package brine yeasts were identified in 13 samples, namely one in NOG (sample 4 with C. glabrata); two in NTCO (samples 3 and 5 with C. krusei); two in GO (samples 3 and 4), three in BO (samples 1, 6 and 7); and five in NOt (samples 3-7).

C. boidinii was the most frequent specie in the pulp, and it was detected mainly in NOt. The presence of $C$. boidinii in table olives has already been mentioned by Arroyo-López et al. (2006) that found this specie was the most frequent in aerobically processed 
Table 5

Yeasts isolated from pulp and packing brine of table olives samples

\begin{tabular}{|c|c|c|c|c|}
\hline \multirow[t]{2}{*}{ Yeasts } & \multicolumn{2}{|l|}{ Pulp } & \multicolumn{2}{|l|}{ Brine } \\
\hline & No. of samples & $\%$ & No. of samples & $\%$ \\
\hline Candida boidinii & 9 & 62.50 & 1 & 4.2 \\
\hline Candida famata & 1 & 6.25 & 0 & 0.00 \\
\hline Candida glabrata & 3 & 18.75 & 3 & 12.50 \\
\hline Candida krusei & 0 & 0.00 & 12 & 70.80 \\
\hline Candida utilis & 1 & 6.25 & 0 & 0.00 \\
\hline Geotrichum penicillatum & 1 & 6.25 & 2 & 8.30 \\
\hline Kloeckera spp. & 0 & 0.00 & 1 & 4.20 \\
\hline
\end{tabular}

The number of samples with yeast occurs and occurrence (\%).

black table olives and it was also isolated from anaerobically processed black table olives. The dominant yeast in the packing brine was $C$. krusei and it was isolated essentially from brine of olives that come from traditional market and producers (NOt). Its absence in the pulp of olives could be related to its sensitivity to phenolic compounds and to low value of $a_{\mathrm{w}}$. In fact previous works (Pereira et al., 2006; Sousa et al., 2006, 2008) proved that olive pulp is rich in phenols that showed antimicrobial activity.

C. glabrata and C. krusei have emerged as important pathogens, whose clinical isolates have been increasing, being $C$. glabrata associated, specially, to urinary tract, mucosal areas and lungs (Hazen, 1995). On the other hand, C. krusei is an opportunistic yeast of clinical significance that has already been isolated from vaginal tract (Parazzini et al., 2000), skin, fingernails and oral mucosas (Crocco et al., 2004), blood (Pfaller et al., 2003) and mucosal surfaces (Samaranayake, 1997). The presence of C. krusei in brine may be associated to contamination due to lack of hygiene during the processing or manipulation of table olives and it is a matter of concern because it is a multidrug-resistant opportunistic fungal pathogen (Pfaller et al. 2008). This situation is in accordance with the results obtained in microbiological characterization (see Table 3 and 4). On the other side, Fernández et al. (1997) referred that C. krusei, isolated from naturally black olive, was able to produce gas-pocket spoilage that alter the quality and safety of table olives.

In general, the results obtained have shown that the optimization of hygienic procedures in the production process is necessary to improve the quality and safety of table olives, especially of the ones from the traditional market/producers. To reduce the risk of food-borne illness and spoilage, good practices in agriculture (GAP), hygiene (GHP) and manufacturing (GMP) most be improved.

\section{Conflict of interest statement}

The authors declare that there are no conflicts of interest.

\section{Acknowledgements}

The authors are grateful to INTERREG III A Program, Project MOABEPE for financial support of this work.

\section{References}

Anonymous, 1987. Codex Standard for Table Olives (Codex Stan 66-1981 (Rev. 11987)). Codex Alimentarius.

Anonymous, 1997. Api 20 C AUX Analytical Profile Index. BioMerieux S.A. third ed. France.

Anonymous, 2004. Establish Protocols and Guidelines for Table Olive Processing in Australia. A report for the Rural Industries Research and Development Corporation by Stanley George Kailis and David Harris. RIRDC Publication No. 04/136. RIRDC Project No. UWA 59A.
Arroyo-López, F.N., Durán-Quintana, M.C., Ruiz-Barba, J.L., Querol, A., GarridoFernández, A., 2006. Use of molecular methods for the identification of yeast associated with table olives. Food Microbiol. 23, 791-796.

Asehraou, A., Faid, M., Jana, M., 1992. Physico-chemical properties and the microflora of Moroccan black table olives. Grasas Aceites 43, 130-133.

Asehraou, A., Faid, M., 1993. Etude physico-chimique et microbiologique des olives vertes désamérisées en fermentation. Actes Inst. Agron. Vet. (Maroc) 13, 21-26.

Asehraou, A., Peres, C., Brito, D., Faid, M., Serhrouchni, M., 2000. Characterization of yeasts strains isolated from bloaters of fermented green table olives during storage. Grasas Aceites 51, 225-229.

Borcakli, M., Ozai, G., Alperden, I., Ozsan, E., Erdek, Y., 1993. Changes in chemical and microbiological composition of two varieties of olive during fermentation. Grasas Aceites 44, 253-258.

Boskou, G., Salta, F.N., Chrysostomou, S., Mylona, A., Chiou, A., Andrikopoulos, N.K., 2006. Antioxidant capacity and phenolic profile of table olives from the Greek market. Food Chem. 94, 558-564.

COI, 2004. Trade Standard Applying to Table Olives. International Olive Oil Council COI/OT/NC no. 1, Dezembro de 2004.

Crocco, E.I., Mímica, L.M.J., Muramatu, L.M., Garcia, C., Souza, V.M., Ruiz, L.R.B., Zaitz, C., 2004. Identification of Candida species and antifungal susceptibility in vitro: a study on 100 patients with superficial candidiasis. Na. Bras. Dermatol. 79, 689-697.

Decreto-Lei no. 167/2004 de 7 de Julho, Diário da República I série A.

Decreto-Lei no. 170/92 de 8 de Agosto, Diário da República I ${ }^{a}$ série A.

Eltem, R., 1996. Growth and aflatoxin B, production on olives and olive paste by moulds isolated from 'Turkish-style' natural black olives in brine. Int. J. Food Microbiol. 32, 217-223.

Fernández, A.G., Díez, M.J.F., Adams, M.R., 1997. Table Olives. Production and Processing. Chapman \& Hall, London, UK.

Floriano, B., Ruiz-Barba, J.L., Jiménez-Díaz, R., 1998. Purification and genetic characterization of enterocin I from Enterococcus faecium 6T1a, a novel antilisterial plasmid - encoded bacteriocin which does not belong to the pediocin family of bacteriocins. Appl. Environ. Microbiol. 64, 4883-4890.

Franz, C.M.A.P., Holzapfel, W.H., 2004. The genus enterococcus: Biotechnological and safety issues. In: Salminen, S., von Wright, A., Ouwehand, A. (Eds.), Lactic Acid Bacteria: Microbiological and Functional Aspects, third ed. CRC Press.

Hazen, K.C., 1995. New and emerging yeast pathogens. Clin. Microbiol. Rev. 8, 462478.

ISO 6579, 2002. Microbiology of food and animal feeding stuffs - horizontal method for the detection of Salmonella spp.

ISO 6887-1, 1999. Microbiology of food and animal feeding stuffs - preparation of test samples, initial suspension and decimal dilutions for microbiological examination. Part 1: general rules for the preparation of the initial suspension and decimal dilutions.

Marsilio, V., Campestre, C., Lanza, B., 2001. Phenolic compounds change during California-style ripe olive processing. Food Chem. 74, 55-60.

Norma Portuguesa (NP) 1829, 1982. Microbiologia alimentar. Preparação de amostras para análise microbiológica. Instituto Português da Qualidade.

Norma Portuguesa (NP) 2262, 1986. Regras gerais para identificar esporos de Clostridios sulfito redutores. Instituto Português da Qualidade.

Norma Portuguesa (NP) 3005, 1985. Microbiologia Alimentar. Preparação de diluições para análise microbiológica. Instituto Português da Qualidade.

Norma Portuguesa (NP) 3034, 1987. Derivados de frutos e de produtos hortícolas. Azeitonas de mesa. Definição, classificação, características, acondicionamento e marcação. Instituto Português da Qualidade.

Nout, M.J.R., Rombouts, F.M., 2000. Fermented and acidified plant foods. In: Lund, B.M., Baird-Parker, T.C., Gould, G.W. (Eds.), The Microbiological Safety and Quality of Food, vol. I. Aspen Publishers, Inc., Gaithersburg, Maryland.

Oliveira, M., Brito, D., Catulo, L., Leitão, F., Gomes, L., Silva, S., Vilas Boas, L., Peito, A., Fernandes, I., Gordo, F., Peres, C., 2004. Biotechnology of olive fermentation of "Galega" Portuguese variety. Grasas Aceites 55, 219-226.

Parazzini, F., Di Cintio, E., Chiantera, V., Guaschino, S., 2000. Determinants of different Candida species infections of the genital tract in women. Eur. J. Obstet. Gynecol. Reprod. Biol. 93, 141-145.

Pereira, J.A., Pereira, A.P., Ferreira, I.C.F.R., Valentão, P., Andrade, P., Seabra, R., Estevinho, L., Bento, A., 2006. Phenolics compounds, antioxidant potential and antimicrobial activity of table olives from Portugal. J. Agr. Food Chem. 54, 84258431 .

Pfaller, M.A., Diekema, D.J., Messer, S.A., Boyken, L., Hollis, R.J., Jones, R.N.The International Fungal Surveillance Participant Group, 2003. In vitro activities of Voriconazole, Posaconazole, and four licensed systemic antifungal agents against Candida species infrequently isolated from blood. J. Clin. Microbiol. $41,78-83$

Pfaller, P.M.A., Diekema, D.J., Gibbs, D.L., Newell, V.A., Nagy, E., Dobiasova, S., Rinaldi, M., Barton, R., Veselov, A.The Global Antifungal Surveillance Group, 2008. Candida krusei, a multidrug-resistant opportunistic fungal pathogen: geographic and temporal trends from the ARTEMIS DISK antifungal surveillance program, 2001-2005. J. Clin. Microbiol. 46, 515-521.

Romero, C., Brenes, M., Yousfi, K., Garcia, P., Garcia, A., Garrido, A., 2004. Effect of cultivar and processing method on the contents of polyphenols in table olives. J. Agr. Food Chem. 52, 479-484.

Roussos, S., Zaouia, N., Salih, G., Tantaoui-Elaraki, A., Lamrani, K., Cheheb, M., Hassouni, H., Verh, F., Perraud-Gaime, I., Augur, C., Ismaili-Alaoui, M., 2006. Characterization of filamentous fungi isolated from Moroccan olive and olive 
cake: Toxinogenic potential of Aspergillus strains. Mol. Nutr. Food Res. 50, 500506.

Samaranayake, L.P., 1997. Candida krusei infections and fluconazole therapy. Hong Kong Med. J. 3, 312-314.

Sousa, A., Ferreira, I.C.F.R., Barros, L., Bento, A., Pereira, J.A., 2008. Antioxidant potential of traditional stoned table olives "Alcaparras": influence of the solvent and temperature extraction conditions. LWT-Food Sci. Technol. 41, 739-745.

Sousa, A., Ferreira, I.C.F.R., Calhelha, R., Andrade, P., Valentão, P., Seabra, R., Estevinho L., Bento, A., Pereira, J.A., 2006. Phenolics and antimicrobial activity of traditional stoned table olives “Alcaparras”. Bioorg. Med. Chem. 14, 8533-8538. 